\title{
Seagrass in the Control of Hyperglycemic and Hyperlipidemic States of Streptozotocin Induced Diabetic Rats
}

\author{
M Vani, P Uma Maheswari Devi*
}

\section{Vani, P Uma Maheswari Devi*}

Department of Applied Microbiology \& Biochemistry, Sri Padmavati Mahila Visvavidyalayam, Tirupati, INDIA.

\section{Correspondence}

Prof. P. Uma Maheswari Devi,

Dept. of Applied Microbiology \&

Biochemistry, Sri Padmavati Mahila Visva

Vidyalayam (Women's University) Tirupati

517 502, A.P., INDIA.

Phone no: 09848894900 ;

E-mail: umadevi66@gmail.com

History

- Submission Date:16-07-2020;

- Review completed: 11-09-2020;

- Accepted Date: 22-09-2020

DOI : 10.5530/pj.2020.12.232

Article Available online

http://www.phcogj.com/v12/i6s

\section{Copyright}

(C) 2020 Phcogj.Com. This is an open access article distributed under the terms of the Creative Commons Attribution 4.0 International license.

\begin{abstract}
Background: The present study intended to evaluate the beneficial effects of the seagrass Halophila beccarii, against induced diabetes mellitus in rat models. Halophila beccarii is a type of Seagrass abundant in Pulicat Lake of Andhra Pradesh, India. Objective: Evaluating the anti-hyperglycemic and anti-hyperlipidemic properties of seagrass extract in comparison with standards. Materials and Methods: STZ induced diabetic rat models were adopted to analyze the effect of long-term treatment with seagrass extract on blood glucose, $\mathrm{HbA} 1 \mathrm{c}$ and serum lipids. Results: The methanolic extract of seagrass demonstrated a significant drop of blood glucose levels (52\%), in diabetic rats, after $6 \mathrm{~h}$ of supplementation. After 40 days of treatment with $500 \mathrm{mg} /$ day of seagrass extract, STZ diabetic rats exhibited tremendous decrease in fasting blood glucose with significant improvement in glycemic control as evidenced by controlled levels of HbA1c. Lower levels of triglycerides, total cholesterol, LDL and VLDL cholesterols and higher levels of HDL cholesterol in STZ-induced diabetic rats provided an evidence for significant anti hyperlipidemic property of seagrass extract. Conclusion: Phytochemicals of seagrass like phenols, flavonoids and bioactive lipids contribute to the anti-hyperglycemic and anti-hyperlipidemic activities and Halophila beccarii extract serves as a natural supplement in the management of diabetes.

Key Words: Halophila beccarii, Diabetes mellitus, FBG, HbA1c, HDL, LDL.
\end{abstract}

\section{INTRODUCTION}

Diabetes mellitus is an endocrine disorder, with increased levels of glucose resulting from insulin resistance, malfunction or deficiency. The carbohydrates, fats and proteins form the most important part of our diet, helping as sources of energy and body building materials. However, the metabolism of these biomolecules is altered in diabetes. Abnormal plasma lipid and lipoprotein profiles with an increased risk of premature atherosclerosis, coronary insufficiency and myocardial infarction are reported with Diabetes. ${ }^{1}$ In diabetes, particularly in insulin deficiency states there is an aggregation of lipids, which poses a threat of developing different types of errors in their metabolism manifested as hypercholesterolemia and hypertriglyceridemia. ${ }^{2}$ This abnormal accumulation of fat, particularly in liver and muscle, provokes insulin resistance that terminate beta cell generation in diabetes. The currently used oral drugs like glibenclamide and metformin for the treatment of diabetes cause adverse side effects such as gastrointestinal disorder, renal failure and pancreatitis. Hence, there is huge need for alternative therapies for the effective management of diabetes particularly in the control of glucose levels along with lipid homeostasis to alleviate the cardiovascular complications.

A large portion of population in the world is completely dependent on traditional medicines and from centuries, herbal remedies have been used for the treatment of diabetes..$^{3-4}$ In Ayurvedic medicine, a number of medicinal plants and their formulations are used for treating diabetes. This native form of medicine uses the active component present in plants for treating diseases. ${ }^{5}$ In addition to terrestrial plants, the marine plants like seagrasses are gaining popularity due to their adaptation to the marine environment. Seagrass appears as meadows and fasten to the ocean by thick root system and rhizomes. Seagrasses are abundant in the Asia pacific region specifically in India. More than fifteen species of seagrass are identified from India. The majority of the seagrass plants belonging to the family Hydrocharitaceae are found in south east coast of Tamil Nadu, Andaman and Nicobar islands.

The seagrass is rich in phyto-constituents like phenols, flavonoids, vitamin E\&C and bioactive lipids. Due to the presence of high phenolic content and unsaturated fatty acids the seagrass extract may serve as a nutraceutical for diabetic patients. However, so far the anti-hyperglycemic and anti hyperlipidemic activity of this marine plant has not been systematically determined. In the present study, an effort has been made to analyse the anti hyperglycemic and anti hyperlipidemic activity of seagrass Halophila beccarii methanolic extract in streptozotocin induced diabetic rats.

\section{MATERIALS AND METHODS}

\section{Collection of Seagrass}

The seagrass plants were collected from the sea coast near Pulicat lake at Nellore district, AP, India. The collected plants were brought to the laboratory under aseptic condition and identified as Halophila

Cite this article: Vani M, PUM Devi. Seagrass in the Control of Hyperglycemic and Hyperlipidemic States of Streptozotocin Induced Diabetic Rats. Pharmacogn J. 2020;12(6) Suppl:1716-21. 
beccarii. ${ }^{6}$ The plants were washed with tap water and washed material was shade dried and the dried samples were then ground to a fine powder.

\section{Preparation of methanolic extract}

The seagrass methanolic extract (SME) was prepared by soaking $20 \mathrm{~g}$ of dried powder of seagrass Halophila beccarii in $200 \mathrm{ml}$ of methanol for seven days at room temperature as per the standard protocol developed in our laboratory. ${ }^{7}$

\section{Experimental Animals}

Male albino rats (180 - $200 \mathrm{~g})$ were maintained on a standard pellet diet and provided access to water and libitum. They were housed in standard environmental conditions i.e. $12 \mathrm{hrs}$ light and $12 \mathrm{hrs}$ dark cycle, as per the guidelines and approval from animal ethical committee of Sri Padmavati Mahila Visvavidyalayam, Tirupati (1677/Po/S/2012/ CPCSEA/30).

\section{Induction of diabetes}

The diabetes was induced in the experimental Wistar rats by adopting standard method. ${ }^{8}$ In brief, a dose of streptozotocin (STZ $50 \mathrm{mg} / \mathrm{kg}$ bwt) dissolved in cold freshly prepared $0.01 \mathrm{M}$ citrate buffer $\mathrm{p}^{\mathrm{H}} 4.5$, was administered to $12 \mathrm{~h}$ fasted rats by intraperitoneal injection. The animals were allowed to drink $5 \%$ glucose solution to overcome the drug-induced hypoglycemia. After 72 hours of injection, the rats with fasting blood glucose levels greater than $250 \mathrm{mg} / \mathrm{dl} /$ or $15 \mathrm{mM} / \mathrm{l}$ were marked as diabetic and utilized as in vivo diabetic model for further experimental analysis.

\section{Assessment of Anti-hyperglycemic activity}

To assess the impact of SME on STZ- induced diabetes. The animals were divided into five groups and each consisted of six rats.

The normal (group-I) and diabetic control (group-II) rats were fed with distilled water alone. After an overnight fasting, the diabetic rat groups III, IV, V were received 250, 500, $750 \mathrm{mg}$ of SME dissolved in 1 $\mathrm{ml}$ of distilled water by gastric intubation using a force-feeding needle. Blood samples were collected from the tail vein at $0,1,2,3,4,5$ and $6 \mathrm{~h}$ after the administration of SME and standard blood glucose levels were determined by using Accu-chek glucometer by oxidase-peroxidase reactive strips.

\section{Effect of long-term supplementation of SME on glycemic control and lipid profiles in diabetic rats}

The rats were divided into five groups with six rats in each group

Group 1: Normal untreated rats

Group 2: Normal rats treated with $500 \mathrm{mg} \mathrm{SME} / \mathrm{kg}$ BW.

Group 3: Diabetic untreated rats

Group 4: Diabetic rats treated with $500 \mathrm{mg}$ SME/kg BW.

Group 5: Diabetic treated rats with $20 \mathrm{mg}$ glibenclamide/ kg BW

Group 1 and Group 3 rats were given distilled water alone (vehicle) daily. The extract was administered at the selected dosage every day for 40 days dissolved in the same vehicle. At the end of the long treatment on $40^{\text {th }}$ day after an overnight fast, blood was collected by retro-orbital puncture from all animals, and the rats were sacrificed by anesthetizing with chloroform and the animals were dissected by cervical dislocation. Plasma was separated immediately and then stored at $-20^{\circ} \mathrm{C}$ till further biochemical investigations. Blood glucose, glycosylated hemoglobin and lipid parameters were analyzed using standard methods. The collected tissues were stored at $-20^{\circ} \mathrm{C}$ for further histopathological analysis.

\section{Biochemical analysis}

Glucose oxidase-peroxidase method was implemented for measuring blood glucose. ${ }^{9}$ Hemoglobin and HbAlc of blood was determined by the cyanmethemoglobin method The amount of cholesterol in the blood sample was determined as per the standard method. ${ }^{10}$ Serum Triglycerides, High-density lipoproteins HDL, low-density lipoproteins (LDL) and very low-density lipoproteins (VLDL) was estimated by the method of Burstein et $a l^{11}$ by using the formula. $\mathrm{LDL}=\mathrm{TC}-(\mathrm{HDL}+$ $\mathrm{VLDL}) / \mathrm{LDL}=[(\mathrm{TC}-\mathrm{HDL})-\mathrm{TG} / 5] \mathrm{VLDL}=\mathrm{TG} / 5$. Atherogenic index was calculated by using the formula, TC-HDL-C/HDL-C. ${ }^{12}$

\section{Histopathology}

After 40 days the rats were dissected, the pancreas was removed and fixed in formalin. The pancreas was processed and sectioned at $5 \mathrm{~m}$ thickness and stained with hematoxylin and eosin staining.

\section{Statistical Analysis}

All the experiments were performed in triplicates and $n=6$ unless otherwise noted, and values represented as mean \pm SEM calculated using Graph pad prism version 7.0. The results were subjected to OneWay ANOVA and statistical significance is denoted by an asterisk ${ }^{*}$ ) when $p$ values are ${ }^{*} p<0.03$ to $0.05,{ }^{*} p<0.001,{ }^{* *} p<0.0001$ and ${ }_{* * * *}^{*} p<0.00001$.

\section{RESULTS}

\section{Anti-hyperglycemic activity of SME}

The experimental rats induced with STZ demonstrated significantly higher levels of fasting blood glucose compared to normal rats. During sub-acute analysis, the STZ diabetic rats treated with SME exhibited a dose dependent anti-hyperglycemic activity. Among the three groups, Group-IV administered with $500 \mathrm{mg} / \mathrm{ml}$ showed $52 \%$ reduction in FBG levels compared with $32 \%$ and $37 \%$ with Group III and Group V STZrats respectively. From the results, the $500 \mathrm{mg} / \mathrm{kg}$ bwt of methanolic extract ' of Halophila beccarii was considered as an effective dosage in controlling the blood glucose levels (Table 1).

\section{Long-term influence of SME on blood glucose, total $\mathrm{Hb}$} and glycosylated hemoglobin

After 40 days of induction with STZ, the rats showed significantly higher levels of fasting blood glucose with drastic decrease in body weight. A tremendous reduction in blood glucose from $384 \pm 5.01$ $\mathrm{mg} / \mathrm{dl}$ to $96 \pm 8.03 \mathrm{mg} / \mathrm{dl}$ and regained body weight was ascertained with supplementation of $500 \mathrm{mg} / \mathrm{kg}$ SME (Table 2). In diabetic rats, glycosylated hemoglobin (HbA1c) of blood reached to $12.5 \mathrm{mg} / \mathrm{dl}$, which is in contrast to normal control group i.e. $5.4 \mathrm{mg} / \mathrm{ml}$. In contrast, HbA1c levels were drastically dropped to $6.2 \pm 1.4$ demonstrating the impact of SME on glycemic control in STZ-induced diabetic rats and the effect was found to be higher when compared with Glibenclamide $(7.0 \pm 1.5)$.

\section{Anti-Hyperlipidemic activity of SME}

The influence of SME on the serum lipid profile of STZ-induced diabetic rats was analyzed. Rats in diabetic control group displayed remarkable rise in the quantity of total cholesterol, triglycerides, LDL-C and VLDL-C compared to normal rats. In contrast, DC group exhibited decreased levels of HDL-C (Figure 1). Rats supplemented with SME and glibenclamide demonstrated a rapid reduction in the quantity of total cholesterol, triglycerides, LDL-C and VLDL- C with concurrent increase in HDL- C content.

The rise in Atherogenic index implies the lipid abnormalities in diabetes. In the experimental analysis, with supplementation of SME a 
Table 1: Percentage reduction in Blood glucose levels at different time points after oral administration of seagrass methanolic extract at $250 \mathrm{mg} / \mathbf{k g} /$ BW. $500 \mathrm{mg} / \mathrm{kg} / \mathrm{BW}$ and $750 \mathrm{mg} / \mathrm{kg} / \mathrm{BW}$ in STZ- induced diabetic rats.

\begin{tabular}{|c|c|c|c|c|c|c|c|}
\hline Groups & Ohr & $1 \mathrm{hr}$ & $2 \mathrm{hr}$ & $3 \mathrm{hr}$ & $4 \mathrm{hr}$ & $5 \mathrm{hr}$ & $6 \mathrm{hr}$ \\
\hline $\begin{array}{l}\text { Group-I } \\
\text { Normal control }\end{array}$ & $98 \pm 5.03$ & $92 \pm 4.2$ & $94 \pm 13.7$ & $89 \pm 11.1$ & $99 \pm 9.4$ & $88 \pm 8.50$ & $88.1 \pm 7.9$ \\
\hline $\begin{array}{c}\text { Group- II } \\
\text { Diabetic control }\end{array}$ & $328 \pm 35.2 \dagger$ & $348 \pm 14.7$ & $340 \pm 7.7$ & $359 \pm 12.5$ & $373 \pm 1.7$ & $332 \pm 8.7$ & $395 \pm 16.3$ \\
\hline $\begin{array}{c}\text { Group-III } \\
\text { Diabetic Treated } \\
(250 \mathrm{mg} / \mathrm{ml})\end{array}$ & $368 \pm 45.7 \dagger$ & $357 \pm 35.6$ & $364 \pm 44.0$ & $303 \pm 47.04$ & $308 \pm 50.2$ & $295 \pm 60.3^{* *}$ & $\begin{array}{c}250 \pm 2.02^{* *} \\
\quad(32 \%)\end{array}$ \\
\hline $\begin{array}{c}\text { Group-IV } \\
\text { Diabetic treated } \\
(500 \mathrm{mg} / \mathrm{kg} \mathrm{b.w})\end{array}$ & $358 \pm 15.8 \dagger$ & $324 \pm 19.6$ & $311 \pm 17.8^{*}$ & $293 \pm 24.5^{\star *}$ & $\begin{array}{l}255 \pm 9.6^{* *} \\
\quad(28 \%)\end{array}$ & $\begin{array}{l}225 \pm 10.2^{* *} \\
(34 \%)\end{array}$ & $\begin{array}{c}170 \pm 8.05^{*} \\
(52.0 \%)\end{array}$ \\
\hline $\begin{array}{c}\text { Group-V } \\
\text { Diabetic treated } \\
(750 \mathrm{mg} / \mathrm{kg} \mathrm{b.w}\end{array}$ & $472 \pm 15.3 \dagger$ & $406 \pm 7.6$ & $340 \pm 8.1$ & $316 \pm 10.5^{*}$ & $338 \pm 8.7^{*}$ & $320 \pm 9.7^{* *}$ & $\begin{array}{c}295 \pm 2.40^{* *} \\
(37.5 \%)\end{array}$ \\
\hline
\end{tabular}

Values are given as mean \pm SEM from six rats in each group, statistical significance $(\mathrm{p} \leq 0.05)$

Table 2: Effect of SME on fasting blood glucose, total $\mathrm{Hb}$, glycosylated $\mathrm{Hb}$ and change in body weights of normal and diabetic rats. NC (normal treated with saline), NT (normal treated with SME), DC (diabetic control), DG (diabetic treated with Glibenclamide), DT (diabetic treated with SME).

\begin{tabular}{|c|c|c|c|c|c|}
\hline \multirow[b]{2}{*}{ Groups } & \multicolumn{2}{|c|}{ Fasting blood glucose } & \multirow[b]{2}{*}{$\mathrm{Hb}(\mathrm{g} / \mathrm{dl})$} & \multirow[b]{2}{*}{ HbA1c } & \multirow[b]{2}{*}{$\begin{array}{c}\text { Change in body } \\
\text { weight }\end{array}$} \\
\hline & Before treatment & $\begin{array}{c}\text { Treatment after } 40 \text { days } \\
\text { with SME }\end{array}$ & & & \\
\hline $\mathrm{NC}$ & $98 \pm 8.5^{\mathrm{a}}$ & $110 \pm 2.10$ & $14.5 \pm 1.5^{\mathrm{c}}$ & $5.4 \pm 0.5^{\mathrm{a}}$ & +40 \\
\hline NT & $90 \pm 7.07^{\mathrm{a}}$ & $100 \pm 2.03$ & $14.2 \pm 1.2^{\mathrm{c}}$ & $4.5 \pm 1.2^{c}$ & +60 \\
\hline $\mathrm{DC}$ & $384 \pm 5.01^{\mathrm{a}}$ & $450 \pm 2.01^{\mathrm{a}}$ & $7.5 \pm 1.8^{\mathrm{d}}$ & $12.5 \pm 1.6^{\mathrm{d}}$ & -35 \\
\hline DG & $463 \pm 5.03^{c}$ & $140 \pm 5.03$ & $12.8 \pm 1.6^{\mathrm{c}}$ & $7.0 \pm 1.5^{c}$ & +30 \\
\hline DT & $350 \pm 14.01$ & $96 \pm 8.03^{b}$ & $13.2 \pm 2.0^{\mathrm{d}}$ & $6.2 \pm 1.4^{c}$ & +60 \\
\hline
\end{tabular}

Values are given as mean \pm SEM from six rats in each group, statistical significance $(\mathrm{p} \leq 0.05)$.

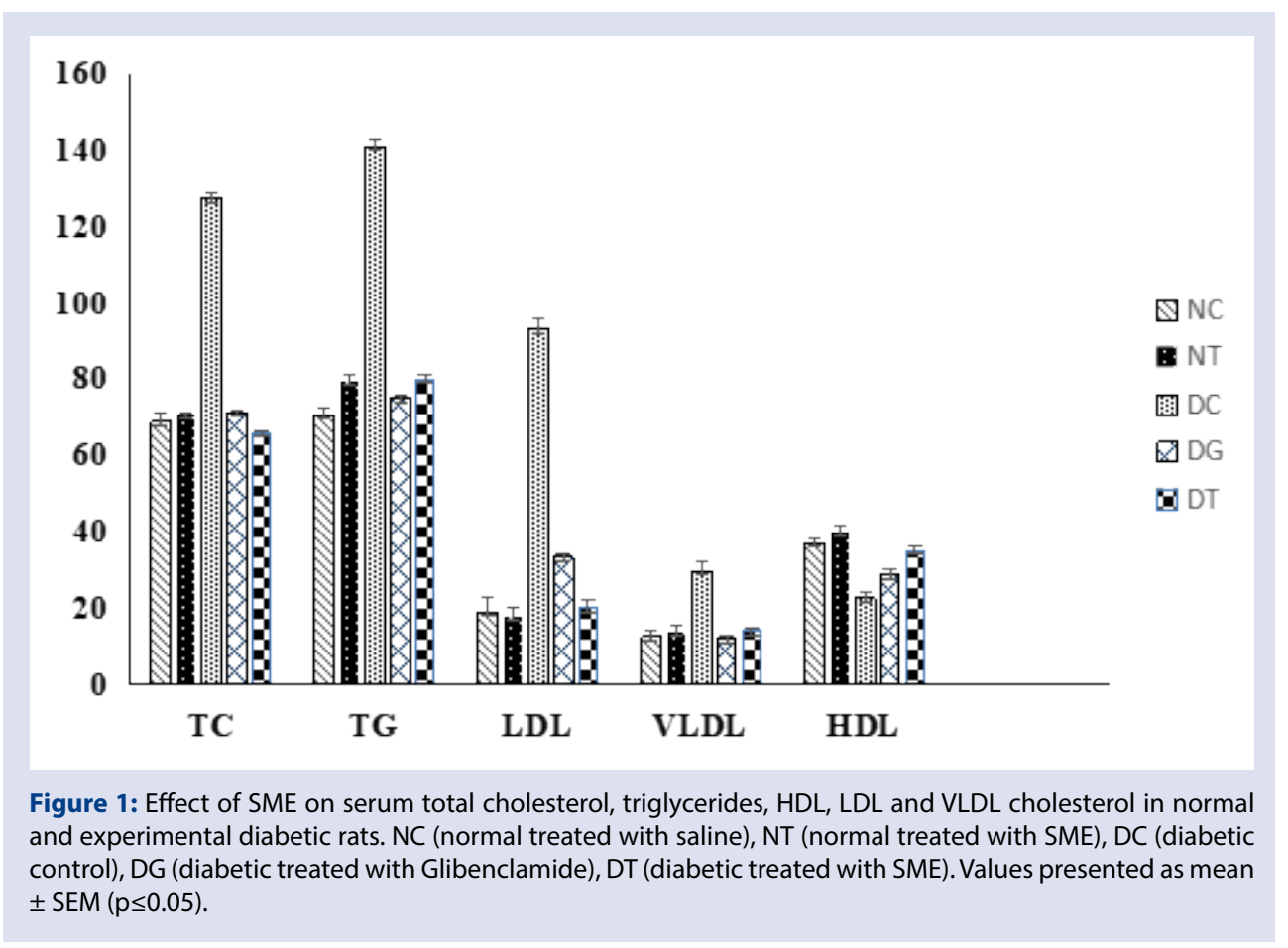

5 -fold decrease in atherogenic index was encountered (Figure 2). There was a reduction of atherogenic index form 4.64 in DC group to 0.88 with supplementation of SME in STZ diabetic rats. The atherogenic index (0.88) in SME treated rats is lower in comparison to both the DC (4.64) and DG (1.49) groups.

\section{Effect of SME on tissue of pancreas}

Pancreatic sections of normal control rats showed entire histological features of endocrine and exocrine components (Figures 3a,b). STZ- induced diabetic rats showed necrotic and degenerative changes in the islets of Langerhans and decreased number of beta cells as represented in Figure 3c. Treatment with SME and glibenclamide prevented the histological changes and thereby caused a significant decrease in the damage of pancreatic tissue (Figures 3d,e).

\section{DISCUSSION/ CONCLUSION}

Streptozotocin (STZ) is renowned for its cytotoxic activity against pancreatic islet $\beta$-cells, which results in inadequate secretion of insulin, 


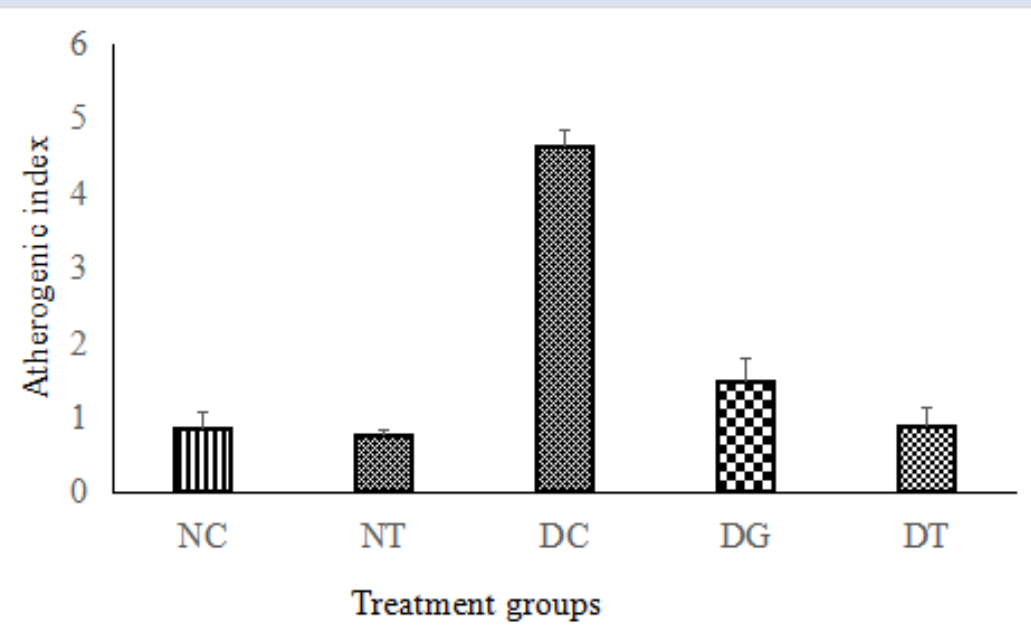

Figure 2: Effect of SME on atherogenic index in normal and experimental diabetic rats. NC (normal treated with saline), NT (normal treated with SME), DC (diabetic control), DG (diabetic treated with Glibenclamide), DT (diabetic treated with SME). Values are given as mean \pm SEM $(\mathrm{p} \leq 0.05)$

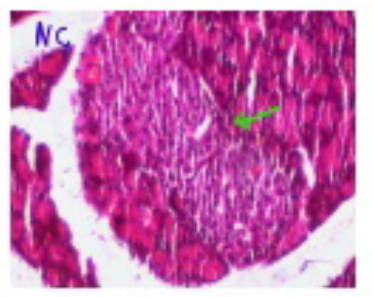

A. Normal control

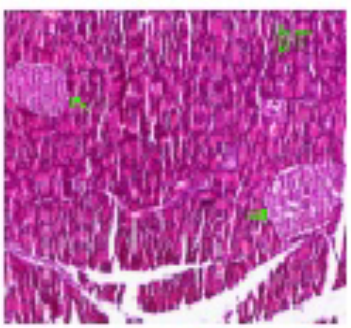

D. SME treated

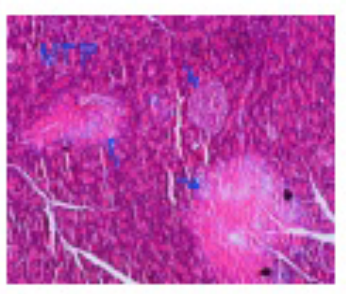

B. Normal treated

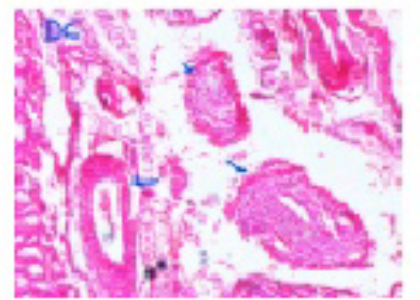

C. Diabetic control

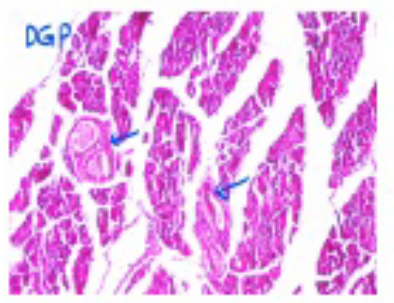

\section{E. Glibenclamide treated}

Figure 3: Effect of SME \& glibenclamide on STZ-induced diabetic rat pancreas a) Normal control rat pancreas b) Normal treated (HBME) rat pancreas c) Diabetic control rat pancreas d) HBME treated Diabetic rat pancreas.

the hallmark feature of type 2 diabetes. ${ }^{13} \mathrm{STZ}$ is commonly used to induce diabetes mellitus in experimental rats. ${ }^{14} \mathrm{STZ}$ enters into the $\beta$-cells of pancreas through glucose transporters GLUT2, which facilitates poly-ADP ribosylation and nitric oxide release that lead to the destruction of pancreatic $\beta$-cells. ${ }^{15}$ To the best of our knowledge, the present study is the first report that evaluates the anti-diabetic activity of SME on STZ-diabetes induced experimental rats.

During the in vivo analysis for anti-hyperglycemic activity of seagrass, the rats were induced with diabetes by streptozotocin at a dose level of $500 \mathrm{mg} / \mathrm{kg}$ bwt in $0.1 \mathrm{M}$ cold citrate buffer. Different doses of SME ( $250 \mathrm{mg} / \mathrm{kg}$ bwt, $500 \mathrm{mg} / \mathrm{kg}$ bwt and $750 \mathrm{mg} / \mathrm{kg}$ bwt) tested for glucose lowering capacity in a short-term study. The SME evidently showed a hypoglycemic effect by decreasing the fasting blood glucose levels up to $52 \%$ in STZ induced diabetic animals within $6 \mathrm{~h}$. The SME at a dose level of $500 \mathrm{mg} / \mathrm{kg}$ bwt exhibited pronounced anti-diabetic activity.

In long-term analysis, the STZ-diabetes rats exhibited reduction in body weight, which might be due to enhanced catabolism of proteins to free amino acids. The amino acids stimulate the process of gluconeogenesis due to the lack of carbohydrates for glycolysis and oxidative phosphorylation. Our results were in tune with earlier research with decreased body weight in STZ-diabetic rats ${ }^{16}$. Unlike the diabetic group, the SME administered groups demonstrated the steady raise in the body weight. Thus, the data indicates the promising effect of SME supplementation against the weight loss caused by STZ during induction period. 
Normalization of blood glucose levels in SME administered rats confirms the anti-hyperglycemic activity of SME instead of hypoglycemic activity. The feasible mechanism of anti-hyperglycemic activity of SME might be due to bioactive fatty acids and phenols of Halophila beccarii, which play an important role in the regeneration of pancreatic $\beta$ cells. These phyto-constituents might perform insulin like function either by uptake of glucose or inhibition of hepatic gluconeogenesis. The decreased FBG levels in diabetic rats are due to the regeneration of pancreatic $\beta$ cells by SME. The effect of SME on reduction of FBG initiated at $11^{\text {th }}$ day of dose administration. The insulin secretion was high with SME compared to glibenclamide, which induces insulin secretion from beta cells by the process of exocytosis.

In diabetic condition, the increased circulating blood glucose react non-enzymatically with hemoglobin to form glycosylated hemoglobin (HbAlc) as a result total hemoglobin concentration was decreased. ${ }^{17}$ It is formed progressively and irreversibly over a period and is stable until the life of the RBC and is unaffected by diet, insulin or exercise on the day of testing. ${ }^{18}$ The amount of glycosylated hemoglobin (HbAlc) is correlated with the blood glucose level that predicts the risk for the development and/or progression of diabetic complications. ${ }^{19}$ Glycosylated hemoglobin indicates the rate of glycation of protein and it is a significant marker for the identification of stages of diabetes. $\mathrm{HbAlc}$ levels were used as an objective measure of glycemic control and its screening is useful for determining the high-risk level of diabetes. Decreased hemoglobin levels and increased HbAlc levels in STZ-diabetic rats was significantly restore to normal after treating the STZ-diabetic rats with SME. Oral administration of SME decreased the HbAlc levels in diabetic rats by its anti-hyperglycemic activity. The normal level of glycosylated hemoglobin demonstrates the reduced glycation of protein and it confirms the anti-hyperglycemic potential of seagrass.

In this present analysis, induction of diabetes with STZ caused severe pathological changes such as chronic pancreatitis, chronic inflammation and periductal fibrosis in the pancreas tissues. On treatment with SEM and glibenclamide, the pathological changes were totally altered and pancreatic tissue seems to be normal. This indicates the effect of SEM on regeneration of damaged pancreas and explains the potential of SEM in the management of diabetes.

Diabetes is associated with elevated levels of circulating free fatty acids particularly in VLDL with an enhanced risk of initial atherosclerosis and myocardial infarction..$^{20}$ Along with the regulation of carbohydrate metabolism, insulin acts as anti-lipolytic agent and controls the catabolism of fats in the body. Accumulation of lipids in diabetes is mainly due to insulin deficiency. ${ }^{21}$ STZ-induced rats showed higher concentration of TC (45\%) and TG (50\%) compared to normal groups. Administration with SME normalized the levels of TC and TG. Further SME drastically lowered the levels of LDL and VLDL-c and exerted positive improvement on HDL.

Hyper-triglyceridemia is a common metabolic disorder in patients with diabetes mellitus, which leads to vascular complications. ${ }^{22}$ Bruan and Severson ${ }^{23}$, reported that the insufficient production of lipoprotein lipase results in the elevation of triglycerides in diabetes mellitus. Treatment of diabetes with insulin helped to lower the plasma triglycerides by returning lipoprotein lipase to normal levels. ${ }^{24}$ Several reports on studies of diabetes mellitus displayed that the synthesis of free radicals and decrease in cells antioxidant activities is due to the existence of oxidative stress. ${ }^{25}$

In the present study, the SME significantly reduced the triglyceride, total cholesterol, LDL and VLDL cholesterol levels with an increase of HDL cholesterol in treated diabetic rats as compared to untreated diabetic rats. The significant control of the levels of serum lipids in the SME treated diabetic rats may be directly attributed to improvement in glycemic control upon SME therapy.

The present study concludes the anti hyperglycemic and anti hyperlipidemic activities of methanolic extract of seagrass. Thus, searass extract may be used as nutracuetical supplement or adjuvant for the management of diabetes and cardiovascular complications.

\section{ACKNOWLEDGEMENT}

CURIE laboratory, Sri Padmavati Mahila Visvavidyalayam, Tirupati.

\section{CONFLICTS OF INTEREST}

Nil.

\section{REFERENCES}

1. Yahaya SF, Suleiman MM, Mohammed A, and Ibrahim NDG. Anti-diabetic potentials of stem-bark extracts of Terminalia avicennioides on alloxan-induced diabetic rats. Sokoto J. Vet. Sci. 2019;17(2):33-44.

2. Stamler J, Vaccaro O, Neaton JD, Wentworth D. Multiple Risk Factor Intervention Trial Research Group. Diabetes, other risk factors, and 12-yr cardiovascular mortality for men screened in the Multiple Risk Factor Intervention Trial. Diabetes care. 1993;16(2):434-44.

3. Vijayalakshmi $\mathrm{K}$, and Selvaraj $\mathrm{Cl}$. Evaluation of antidiabetic potential of Sarcostemma brevistigma Wight \& Arn. Using alloxan-induced diabetic murine model. Appl. Biochem. \& Biotech. 2019;187(1):14-27.

4. Feshani AM, Kouhsari SM, Mohammadi S. Vaccinium arctostaphylos, a common herbal medicine in Iran: molecular and biochemical study of its antidiabetic effects on alloxan-diabetic Wistar rats. J. Ethnopharmaco. 2011;133(1): 67-74.

5. Lewis WH, and Elvin-Lewis MP. Medical botany: plants affecting human health. John Wiley \& Sons. $2^{\text {nd }}$ ed 2003.

6. Vani M, Vasavi T, Uma P. Evaluation of in vitro Anti-diabetic activity of methanol extract of seagrass Halophila beccarii. Asian J Pharm Clin Res. 2018;11(8)150-3.

7. Vani M, Murthy SDS, Uma Maheswari Devi P. Phytochemicals and in-vitro antioxidant activity of Halophila beccarii. Int J of Pha Sci and Res. 2019; 10(3):1347-53.

8. Williamson JR, Browning ET, and Scholz R. Control mechanisms of gluconeogenesis and ketogenesis I. Effects of oleate on gluconeogenesis in perfused rat liver. J. Biolog. Chem. 1969;244(17):4607-16.

9. Johnson RN, Baker JR. Accuracy of devices used for self-monitoring of blood glucose. Ann Clin Biochem. 1998;35(1):68-74

10. Zlatkis $A$, Zak B, Boyle AJ. A new method for the direct determination of serum cholesterol. J Lab Clin Med. 1953;41(3):486-92.

11. Burstein MS, Scholnick HR, Morfin R. Rapid method for the isolation of lipoproteins from human serum by precipitation with polyanions. J. lipid Res. 1970;11(6):583-95

12. Suanarunsawat T, Ayutthaya WD, Songsa T, Rattanamahaphoom J. Anti-lipidemic actions of essential oil extracted from Ocimum sanctum (L). leaves in rats fed with high cholesterol diet. J. Appl. Biomed. 2009;7(1):45-53.

13. Gomes A, Vedasiromoni JR, Das M, Sharma RM, Ganguly DK. Antihyperglycemic effect of black tea (Camellia sinensis) in rat. J. Ethnopharmacol. 1995; 45(3): 223-6.

14. Maritim AC, Sanders RA, Watkins lii JB. Effects of $\alpha$-lipoic acid on biomarkers of oxidative stress in streptozotocin-induced diabetic rats. J. Nutr. Biochem. 2003;14(5):288-94.

15. Neethu P, Haseena P, Goveas SW, Abraham A. Antioxidant properties of Coscinium fenestratum stem extracts on Streptozotocin induced type 1 diabetic rats. J. Appl. Pharm. Sci. 2014;4(1):029-032.

16. Hassan SK, El-Sammad NM, Mousa AM, Mohammed MH, Farrag AE, Hashim AN, et al. Hypoglycemic and antioxidant activities of Caesalpinia ferrea Martius leaf extract in streptozotocin-induced diabetic rats. Asian Pac J Trop Biomed. 2015;5(6):462-71.

17. Nabi SA, Kasetti RB, Sirasanagandla S, Tilak TK, Kumar MV, Rao CA Antidiabeticand antihyperlipidemic activity of Piper longum root aqueous extract in STZ induced diabetic rats. BMC Complement Altern Med. 2013;13:37.

18. Tembhurne SV, Sakarkar DM. Protective effect of Murraya koenigii $(L)$ leaves extract in streptozotocin induced diabetics rats involving possible antioxidant mechanism. J. Med. Plant Res. 2010;4(22):2418-23.

19. Gu W, Winters KA, Motani AS, Komorowski R, Zhang Y, Liu Q, et al. Glucagon receptor antagonist-mediated improvements in glycemic control are dependent on functional pancreatic GLP-1 receptor. Amer. J. Physi.Endo. \& Meta. 2010; 299(4):624-32 
20. Brown W. Lipoprotein disorders in diabetes mellitus. Med Clin North Am. 1994;78(1):143-61.

21. Ramachandran $V$, Saravanan $R$, and Senthilraja P. Antidiabetic and antihyperlipidemic activity of asiatic acid in diabetic rats, role of HMG COA: in vivo and in silico approaches. Phytomedicine. 2014;21(3):225-32.

22. Kudchodkar BJ, Lee MJ, Lee SM, DiMarco NM, and Lacko AG. Effect of dietary protein on cholesterol homeostasis in diabetic rats. J lipid Res. 1988; 29(10):1272-87.
23. Braun JE, and Severson DL. Lipoprotein lipase release from cardiac myocytes is increased by decavanadate but not insulin. Am j physiol-endoc $M$ 1992;262(5):663-70

24. Lopes-Virella MF, Wohltmann HJ, Mayfield RK, Loadholt CB, Colwell JA. Effect of metabolic control on lipid, lipoprotein, and apolipoprotein levels in 55 insulindependent diabetic patients: a longitudinal study. Diabetes. 1983;32(1):20-25

25. Descorbeth $M$, and Anand-Srivastava MB. Role of oxidative stress in highglucose-and diabetes-induced increased expression of $\mathrm{Gq} / 11 \alpha$ proteins and associated signaling in vascular smooth muscle cells. Free Radical Biology \& Med. 2010;49(9):1395-05.

\section{GRAPHICAL ABSTRACT}

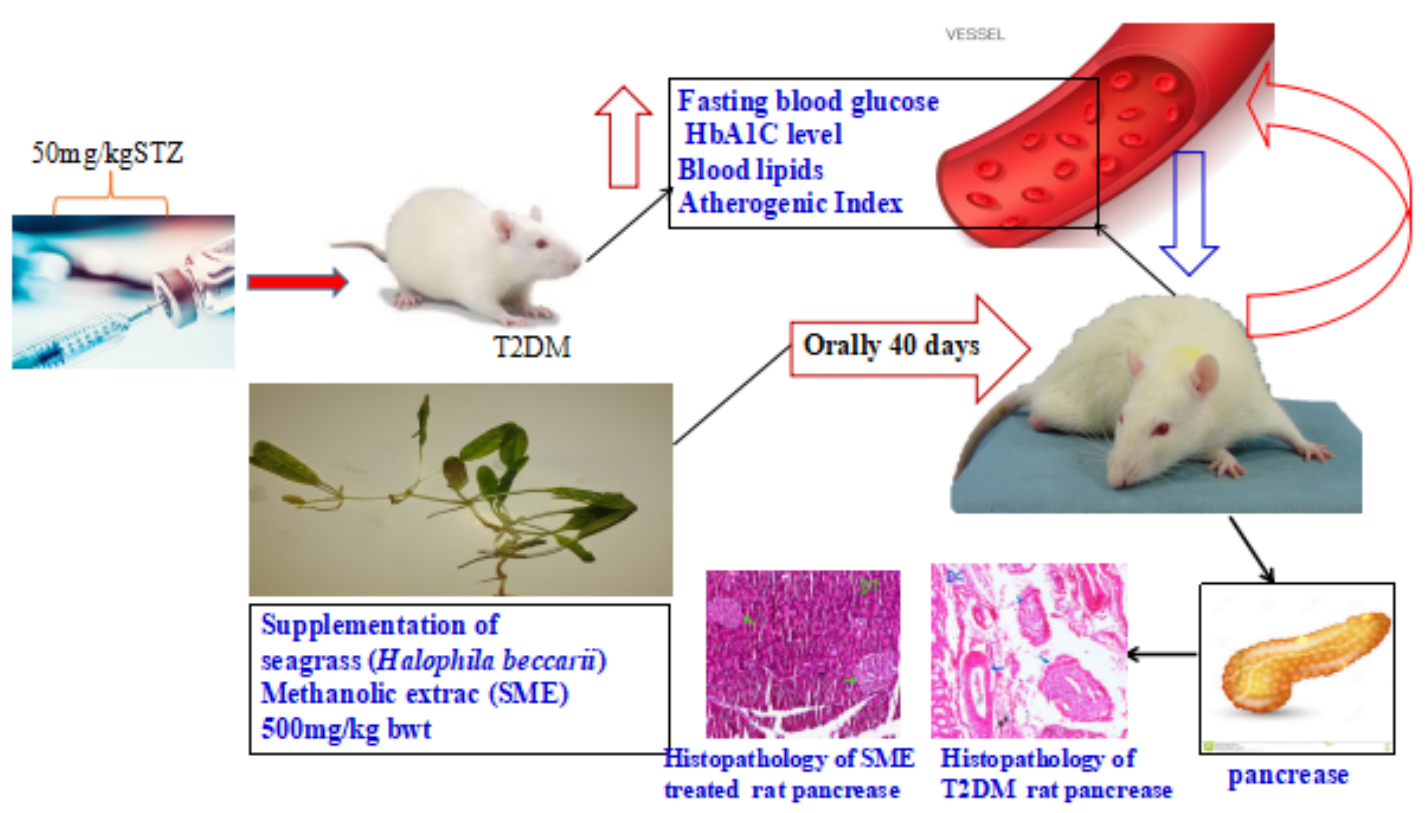

\section{ABOUT AUTHORS}

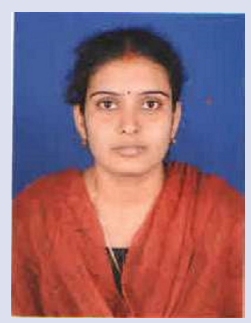

Dr. Vani Mathakala: Is a Ph.D of Biochemistry and faculty in the Department of Applied Microbiology \& Biochemistry, Sripadmavati Mahila UnUniversity, AP, India. She has experience in the area of antidiabetic and anti-inflammatory methods of the animal models and maintenance of 3T3 L1 pre adipocytes fibroblast cell lines in the cell line culture technique laboratory.

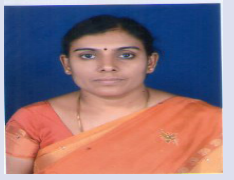

Dr. P.Uma Maheswari Devi is working as Professor in the Department of Applied Microbiology, Sri Padmavati Mahila Visvavidyalayam. Tirupati, Chittoor (Dt.) Andhra Pradesh.She did Post-doctoral fellowships at The Department of Molecular Toxicology on oxylipins and plant microbial interactions in Penn state university, USA Her research interest includes molecular mechanism of immune modulation of inflammation and Diabetes with a specific focus on the transcription of NF- $\kappa B$. She, along with her research team, have a strong focus on natural products \& their therapeutic applications with a long term goal to explore and exploit marine micro biota for therapeutic applications.

Cite this article: Vani M, PUM Devi. Seagrass in the Control of Hyperglycemic and Hyperlipidemic States of Streptozotocin Induced Diabetic Rats. Pharmacogn J. 2020;12(6)Suppl:1716-21. 